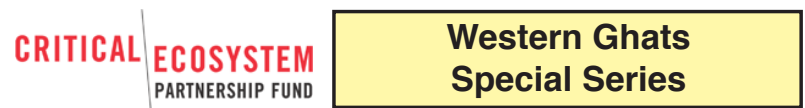

\title{
Freshwater fish fauna of Koyna River, northern Western Ghats, India
}

\author{
Bapurao V. Jadhav ${ }^{1}$, Sanjay S. Kharat ${ }^{2}$, Rupesh N. Raut ${ }^{3}$, Mandar Paingankar ${ }^{4} \&$ Neelesh \\ Dahanukar $^{5}$ \\ ${ }^{1}$ Department of Zoology, Balasaheb Desai College, Patan, Satara, Maharashtra 415206, India \\ ${ }^{2}$ Department of Zoology, Modern College of Arts, Science and Commerce, Ganeshkhind, Pune, Maharashtra 411007, India \\ ${ }^{3}$ Department of Zoology, Elphinstone College, Mumbai, Maharashtra 400032, India \\ ${ }^{4}$ Department of Zoology, University of Pune, Ganeshkhind, Pune, Maharashtra 411007, India \\ ${ }^{5}$ Indian Institute of Science Education and Research, Sai Trinity, Garware Circle, Pune, Maharashtra 411021, India \\ Email: ${ }^{1}$ b_v_jadhav@yahoo.co.in, ${ }^{2}$ kharat.sanjay@gmail.com, ${ }^{3}$ rupesh.raut@gmail.com, ${ }^{4}$ mandarpaingankar@gmail.com, \\ ${ }^{5}$ n.dahanukar@iiserpune.ac.in (corresponding author)
}

\begin{abstract}
We studied the freshwater fish fauna of Koyna River for a period of two years from May 2007 to April 2009. We recorded 58 species belonging to 16 families and 35 genera. Eleven out of the 22 fish species endemic to the Western Ghats are restricted to the Krishna River system. Eight endemic fish species are known to be threatened because of various anthropogenic activities. Since the fish fauna of Koyna is relatively less threatened by anthropogenic stressors with currently no record of alien fish species, we propose that Koyna River can be considered as a refuge for conservation of some endemic and threatened freshwater fishes of the Western Ghats. Nevertheless, efforts to maintain low anthropogenic interference and avoiding introduction of alien species are central to our proposal.
\end{abstract}

Keywords: Conservation, endemics, invasives, refuge, threats.

Date of publication (online): 26 January 2011

Date of publication (print): 26 January 2011

ISSN 0974-7907 (online)| 0974-7893 (print)

Editor: Anonymity requested

Manuscript details:

Ms \# 02613

Received 24 October 2010

Final received 31 December 2010

Finally accepted 17 January 2011

Citation: Jadhav, B.V., S.S. Kharat, R.N. Raut, M. Paingankar \& N. Dahanukar (2011). Freshwater fish fauna of Koyna River, northern Western Ghats, India. Journal of Threatened Taxa 3(1): 1449-1455.

Copyright: ๑ Bapurao V. Jadhav, Sanjay S. Kharat, Rupesh N. Raut Mandar Paingankar \& Neelesh Dahanukar 2011. Creative Commons Attribution 3.0 Unported License. JoTT allows unrestricted use of this article in any medium for non-profit purposes, reproduction and distribution by providing adequate credit to the authors and the source of publication.

Acknowledgements: We are thankful to the Principal, H.D. Shalgaokar, Balasaheb Desai College, Patan for providing facilities. Pallavi and Prajakta Khairmode helped with fish collection. The study was self funded. The CEPF-funded freshwater assessment of the Western Ghats encouraged us to publish this work. We duly acknowledge the help from CEPF for publication of this article. We thank three anonymous referees for comments on an earlier draft of the manuscript.

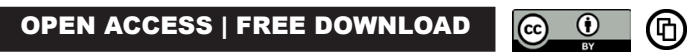

Marathi Abstract: कोयना नदी मधिल गोड्या पाण्यात राहणान्या माशांचा अभ्यास आम्ही मे २००७ ते एप्रिल २००९ ह्या दोन वर्षाच्या कालावधीत केला. आम्हाला एकण ५८ जातीचे मासे आढळले. यातील २२ मत्स्य प्रजाती ह्या फक्त संत्याद्री मध्येंच आढळतात तर १? प्रजाती फक्त कृष्णा नदी व तिला मिळणान्या उपनद्यातच सापडतात. परंतु यातील आठ प्रजातींच्या माइयांची पर्यावरण -्हासामळे नष्ट होण्याची भिती आहे. तुलनात्मक दृष्ट्या कोयना खोज्यात मानवी हस्तक्षेप कमी असल्यामुळे आणि नविन बाह्य मत्स्य प्रजती न सोडल्यामुळे कोयना नदी ही स्थानिक व -हास होण्याच्या मार्गावरील मत्स्य प्रजातींसाठी नंदनवन ठरेल. कोयना नदी मधील मत्स्य प्रजातींचे नंदनवन टिकवण्यासाठी कमीत कमी मानवी हस्तक्षेपास प्रोत्साहन देणे आणि नवीन मत्स्य व मत्स्य बीजे कोयना नदीत सोडण्यावर बंदी घालणे अत्यंत जरुरीचे आहे.

The Western Ghats of India has a rich freshwater fish fauna with a high level of endemism (Shaji et al. 2000; Dahanukar et al. 2004). However, current knowledge of the threats faced by Western Ghats fishes suggests that a major part of this fauna is threatened by human activities and invasive alien fish species (Dahanukar et al. 2004). Thus, knowledge of the diversity and distribution of the fish fauna is essential for designing and implementing conservation strategies. However, data on the fish fauna of the Western Ghats of Maharashtra have limitations as most of the rivers have not been surveyed extensively and checklists for individual rivers are not available. In the present study we document the freshwater fish fauna of the

This article forms part of a special series on the Western Ghats of India,
disseminating the results of work supported by the Critical Ecosystem
Partnership Fund (CEPF), a joint initiative of l'Agence Française de
Développement, Conservation International, the Global Environment
Facility, the Government of Japan, the MacArthur Foundation and the
World Bank. A fundamental goal of CEPF is to ensure civil society is
engaged in biodiversity conservation. Implementation of the CEPF
investment program in the Western Ghats is led and coordinated by the
Ashoka Trust for Research in Ecology and the Environment (ATREE). 


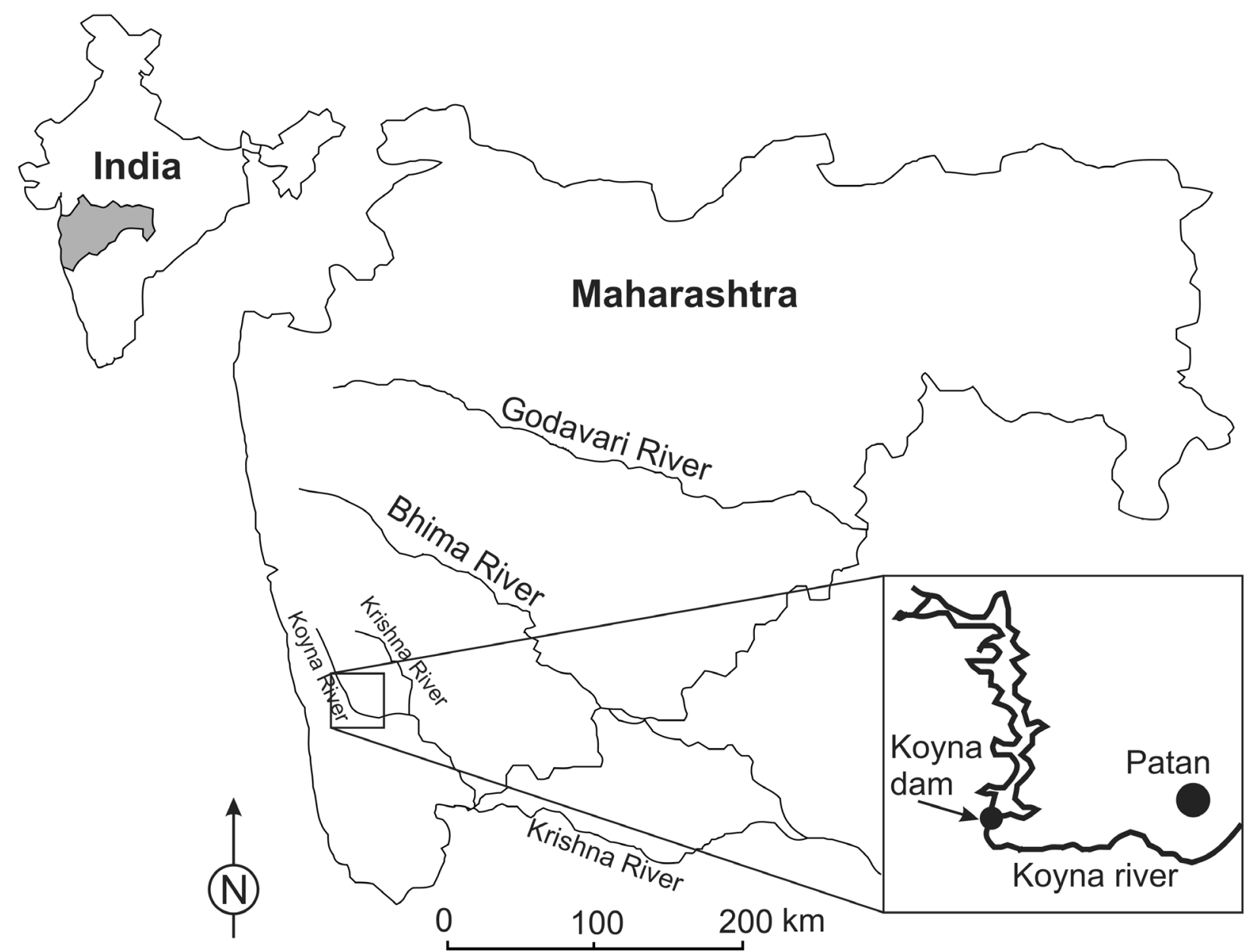

Figure 1. Study site

Koyna River in Satara District, in the northern region of the Western Ghats.

Even though some studies are available on the fishes of Satara District, information on the fish fauna of Koyna River is limited. Annandale (1919) studied the fish fauna of the Yenna River at Medha in Satara and recorded 18 fish species, while Silas (1953) studied the fauna of Mahabaleshwar and Wai in Satara and recorded 14 species. David (1963) made an extensive survey of the Krishna and Godavari river systems, but did not provide data for individual rivers. Similarly, Jayaram (1995) studied the Krishna River system in detail and mentioned that fishes were collected also from the Koyna River; he did not, however, list the species recorded from the Koyna.

The Koyna River (Fig. 1) originates near Mahabaleshwar (17 $\left.58^{\prime} \mathrm{N} \& 7^{\circ} 43^{\prime} \mathrm{E}\right)$ and it is one of the major tributaries of the Krishna River System in western Maharashtra, India. Unlike most of the other rivers in Maharashtra, which flow west-east, the Koyna River flows in a southward direction for about $65 \mathrm{~km}$, turns sharply eastwards at Helwak $\left(17^{0} 22^{\prime} \mathrm{N} \& 7^{\circ} 43^{\prime} \mathrm{E}\right)$, in which direction it flows until its confluence with the Krishna River at Karad (17017'45'N \& 74010'37' E).

We collected fishes from the Koyna River between Koynanagar (17023'34'N \& 73044'20'E) and Patan $\left(17^{0} 22\right.$ '25'N \& 73053'57'E) including small streams draining into this river. Fish were collected for two years, from May 2007 to April 2009. Fish were collected by hand-net in upper stretches in Shiral, Morgiri, Adul, Malhar Peth and Navarasta. In the main river, fish were obtained from local fishermen and local markets at Patan and Koynanagar. Fish were preserved in $4 \%$ buffered formalin and identified using available literature (Menon 1964, 1987, 1992; Talwar \& Jhingran 1991; Jayaram \& Dhas 2000; Jayaram \& Sanyal 2003; Jayaram 1991, 2010). Collected fish 
Table 1. List of freshwater fish from Koyna River.

\begin{tabular}{|c|c|c|c|}
\hline Family/Species ${ }^{a}$ & WGE ${ }^{b}$ & $\mathrm{KRE}^{\mathrm{c}}$ & $\mathbf{R A}^{\mathrm{d}}$ \\
\hline \multicolumn{4}{|l|}{ Notopteridae } \\
\hline Notopterus notopterus (Pallas, 1769) & - & - & $\mathrm{C}$ \\
\hline \multicolumn{4}{|l|}{ Anguillidae } \\
\hline Anguilla bengalensis (Gray, 1831) * & - & - & $\mathrm{R}$ \\
\hline \multicolumn{4}{|l|}{ Cyprinidae } \\
\hline Barilius barna (Hamilton, 1822) & - & - & $\mathrm{C}$ \\
\hline Barilius bendelisis (Hamilton, 1807) & - & - & $M$ \\
\hline Cirrhinus fulungee (Sykes, 1839) & + & + & $\mathrm{C}$ \\
\hline $\begin{array}{l}\text { Crossocheilus cf. latius (Hamilton, } \\
\text { 1822) }\end{array}$ & - & - & M \\
\hline $\begin{array}{l}\text { Devario aequipinnatus (McClelland, } \\
\text { 1839) }\end{array}$ & - & - & $\mathrm{C}$ \\
\hline Garra bicornuta Narayan Rao, 1920 & + & + & $\mathrm{C}$ \\
\hline $\begin{array}{l}\text { Garra gotyla stenorhynchus (Jerdon, } \\
\text { 1849) }\end{array}$ & + & - & M \\
\hline Garra mullya (Sykes, 1839) & - & - & A \\
\hline $\begin{array}{l}\text { Gonoproktopterus curmuca (Hamilton, } \\
1807 \text { ) }\end{array}$ & + & - & $\mathrm{C}$ \\
\hline Labeo boga (Hamilton, 1822) & - & - & $\mathrm{R}$ \\
\hline Labeo boggut (Sykes, 1839) & - & - & M \\
\hline Labeo calbasu (Hamilton, 1822) & - & - & $\mathrm{M}$ \\
\hline Labeo porcellus (Heckel, 1844) & - & - & $\mathrm{R}$ \\
\hline Osteobrama vigorsii (Sykes, 1839) & - & - & $\mathrm{C}$ \\
\hline Osteochilichthys nashii (Day, 1869) & + & - & $\mathrm{M}$ \\
\hline $\begin{array}{l}\text { Osteochilichthys godavariensis (Rao, } \\
\text { 1977) }\end{array}$ & + & - & M \\
\hline $\begin{array}{l}\text { Puntius cf. amphibius (Valenciennes, } \\
\text { 1842) }\end{array}$ & - & - & A \\
\hline Puntius jerdoni (Day, 1870) & + & - & M \\
\hline Puntius sahyadriensis Silas, 1953 & + & + & $\mathrm{C}$ \\
\hline $\begin{array}{l}\text { Puntius sarana subnasutus } \\
\text { (Valenciennes, 1842) }\end{array}$ & + & - & $\mathrm{C}$ \\
\hline Puntius sophore (Hamilton, 1822) & - & - & $\mathrm{C}$ \\
\hline Puntius ticto (Hamilton, 1822) & - & - & A \\
\hline Rasbora daniconius (Hamilton, 1822) & - & - & $\mathrm{C}$ \\
\hline Rohtee ogilbii (Sykes, 1839) & + & + & M \\
\hline Salmophasia balookee (Sykes, 1839) & - & - & $\mathrm{R}$ \\
\hline Salmophasia boopis (Day, 1874) & + & - & A \\
\hline $\begin{array}{l}\text { Salmophasia novacula (Valenciennes, } \\
\text { 1840) }\end{array}$ & + & - & M \\
\hline $\begin{array}{l}\text { Schismatorhynchos nukta (Sykes, } \\
\text { 1839) }\end{array}$ & + & - & $\mathrm{R}$ \\
\hline Tor khudree (Sykes, 1839) & + & - & $\mathrm{C}$ \\
\hline \multicolumn{4}{|l|}{ Parapsilorhynchidae } \\
\hline $\begin{array}{l}\text { Parapsilorhynchus discophorus Hora, } \\
1921\end{array}$ & + & + & $\mathrm{C}$ \\
\hline $\begin{array}{l}\text { Parapsilorhynchus cf. tentaculatus } \\
\text { (Annandale, 1919) }\end{array}$ & - & - & $\mathrm{C}$ \\
\hline \multicolumn{4}{|l|}{ Balitoridae } \\
\hline $\begin{array}{l}\text { Acanthocobitis mooreh (Sykes, 1839) } \\
\star * *\end{array}$ & - & - & M \\
\hline Indoreonectes evezardi (Day, 1872) & - & - & $\mathrm{C}$ \\
\hline
\end{tabular}

\begin{tabular}{|c|c|c|c|}
\hline Family/Species ${ }^{\text {a }}$ & WGE ${ }^{b}$ & $\mathrm{KRE}^{\mathrm{c}}$ & $\mathbf{R A}^{\mathrm{d}}$ \\
\hline $\begin{array}{l}\text { Nemachilichthys rueppelli (Sykes, } \\
\text { 1839) }\end{array}$ & + & + & M \\
\hline $\begin{array}{l}\text { Noemacheilus anguilla Annandale, } \\
1919\end{array}$ & + & + & M \\
\hline Schistura denisoni Day, 1867 & - & - & C \\
\hline \multicolumn{4}{|l|}{ Cobitidae } \\
\hline Botia striata Narayan Rao, 1920 & + & + & $A$ \\
\hline $\begin{array}{l}\text { Lepidocephalichthys thermalis } \\
\text { (Valenciennes, 1846) }\end{array}$ & - & - & A \\
\hline \multicolumn{4}{|l|}{ Bagridae } \\
\hline Mystus bleekeri (Day, 1877) & - & - & M \\
\hline Mystus malabaricus (Jerdon, 1849) & + & - & M \\
\hline Mystus seengtee (Sykes, 1839) & - & - & M \\
\hline Sperata seenghala (Sykes, 1839) & - & - & M \\
\hline \multicolumn{4}{|l|}{ Siluridae } \\
\hline Ompok bimaculatus (Bloch, 1794) & - & - & C \\
\hline \multicolumn{4}{|l|}{ Schilbeidae } \\
\hline Clupisoma taakree (Sykes, 1839) & - & - & M \\
\hline Neotropius khavalchor Kulkarni, 1952 & - & - & $\mathrm{R}$ \\
\hline \multicolumn{4}{|l|}{ Sisoridae } \\
\hline Glyptothorax lonah (Sykes, 1839) & - & - & $\mathrm{R}$ \\
\hline $\begin{array}{l}\text { Glyptothorax cf. poonaensis Hora, } \\
1938\end{array}$ & + & + & $\mathrm{R}$ \\
\hline Glyptothorax trewavasae Hora, 1938 & + & + & $\mathrm{R}$ \\
\hline \multicolumn{4}{|l|}{ Belonidae } \\
\hline Xenentodon cancila (Hamilton, 1822) & - & - & C \\
\hline \multicolumn{4}{|l|}{ Synbranchidae } \\
\hline $\begin{array}{l}\text { Monopterus cf. indicus (Silas \& } \\
\text { Dawson, 1961) }\end{array}$ & + & + & C \\
\hline \multicolumn{4}{|l|}{ Ambassidae } \\
\hline Chanda nama Hamilton, 1822 & - & - & A \\
\hline $\begin{array}{l}\text { Pseudambassis ranga (Hamilton, } \\
\text { 1822) }\end{array}$ & - & - & A \\
\hline \multicolumn{4}{|l|}{ Gobiidae } \\
\hline Glossogobius giuris (Hamilton, 1822) & - & - & C \\
\hline \multicolumn{4}{|l|}{ Channidae } \\
\hline Channa gachua (Hamilton, 1822) & - & - & M \\
\hline Channa marulius (Hamilton, 1822) & - & - & $\mathrm{R}$ \\
\hline \multicolumn{4}{|l|}{ Mastecembalidae } \\
\hline $\begin{array}{l}\text { Mastacembelus armatus (Lacepède, } \\
1800 \text { ) }\end{array}$ & - & - & C \\
\hline
\end{tabular}

a - Taxonomic status as per Jayaram (2010); ${ }^{\text {b }}$ - Western Ghat endemics; c - Krishna river system endemics; ${ }^{d}$ - Relative abundance; A - abundant; C - common; M - moderate; R - rare; * - this species was not collected; its occurrence is based on report by fishermen; ** - Gonoproktopterus kolus is considered as synonym of G. curmuca (Jayaram 2010). However, if they are proved to be different, then our species should be considered as G. kolus as per Jayaram (1991); ${ }^{* * *}$ - Jayaram (2010) mentions this species as $A$. moreh, but the original spelling of species given by Sykes (1839) is A. mooreh; ${ }^{* * *}$ - Jayaram (2010) spells the specific name as $N$. ruppelli, however, Eschmeyer (2010) suggests the spelling $N$. rueppelli. 


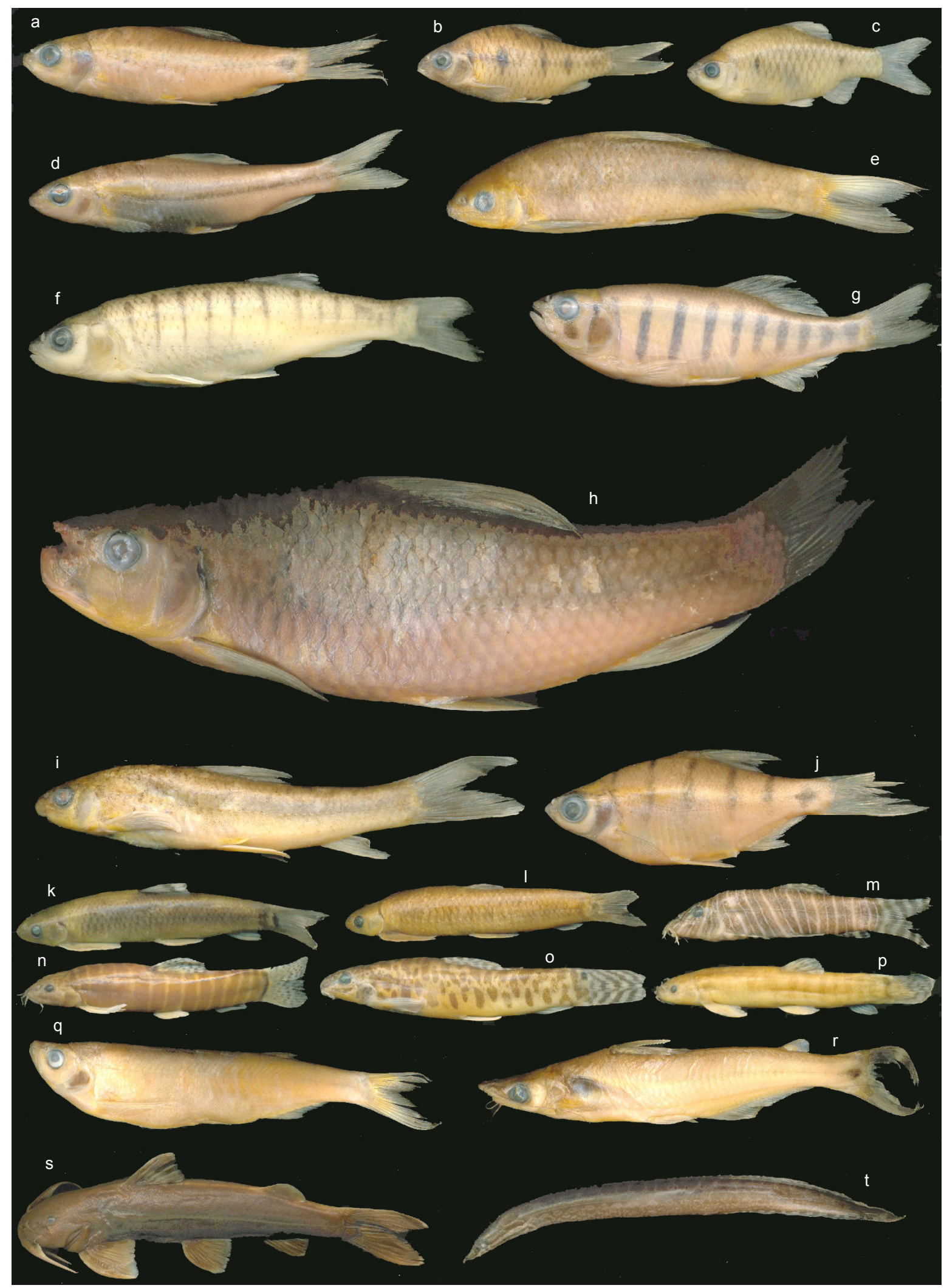

Image 1. Some fishes of the Koyna River.

a - Puntius cf. amphibius; b - Puntius sahyadriensis; c - Puntius ticto; d - Osteochilichthys nashii; e - Osteochilichthys godavariensis; $\mathrm{f}$ - Barilius bendelisis; $\mathrm{g}$ - Barilius barna; $\mathrm{h}$ - Schismatorhynchos nukta; $\mathrm{i}$ - Crossocheilus cf. latius; j - Rohtee ogilbii; k - Parapsilorhynchus discophorus; I - Parapsilorhynchus cf. tentaculatus; m - Botia striata; n - Schistura denisoni; o - Acanthocobitis mooreh; p - Indoreonectes evezardi; q - Salmophasia balookee; r - Neotropius khavalchor; s - Glyptothorax lonah and $\mathrm{t}$ - Mastacembelus armatus. 
specimens, preserved in 4\% buffered formalin are deposited in the Zoology Department of Balasaheb Desai College, Satara and the Zoology Department of Modern College of Arts, Science and Commerce, Ganeshkindh, Pune. Assuming that fishing efforts were constant for a given type of fishing net, the relative abundance of the fish was classified into four categories, namely: abundant (76-100\% of the total catch), common (51-75\% of the total catch), moderate (26-50\% of the total catch) and rare $(1-25 \%$ of the total catch).

We recorded 58 fish species belonging to 16 families and 35 genera (Table 1). Some of the fishes collected from Koyna River are shown in Image 1. Cyprinidae was the most dominant family, contributing 30 species in 15 genera. A total of 22 fish species in the Koyna River are endemic to the Western Ghats, of which 11 are restricted to the Krishna River system (Table 1). Of the total 58 species, eight were abundant, 21 common, 19 moderate and 10 rare in the study area (Table 1).

Five species reported in the current study have ambiguous taxonomic status. Pethiyagoda \& Kottelat (2005, p.151) considered Puntius amphibius to be known only from its lectotype, preserved almost two centuries ago; it remains to be identified with an extant species. In the case of Crossocheilus latius our specimens from Koyna River differ from C. latius sensu stricto in the number of gill rakers (Rui-Feng et al. 2000). Annandale (1919) described Parapsilorhynchus tentaculatus from streams in the Khandala and Yenna River systems near Medha in Satara. Although we did not collect this species from Yenna River, the Koyna River specimens of $P$. tentaculatus do not correspond to our Khandala specimens in body proportions. It is possible that $P$. tentaculatus sensu lato comprises more than a single species. We also procured five specimens of a smoothskinned Glyptothorax from Patan fish market. Even though this species resembles G. poonaensis (Hora 1938; Silas 1951; Talwar \& Jhingran 1991; Jayaram 2010), it differs considerably with larger head length, inter-orbital distance, inter-narial distance, length of dorsal fin, length of adipose dorsal fin, length of ventral fin, length of anal fin and height of caudal peduncle from topotypical G. poonaensis from Pune (specimens in the collection of Zoological Survey of India, Pune: P/2431, P/2432, P/2433). Monopterus indicus sensu stricto, described by Silas \& Dawson (1961) from
Mahabaleshwar in Satara District, differs in having a longer head as compared to Koyna River specimens and possessing a greater number of vertebrae $(\sim 135)$ as compared to fewer vertebrae $(\sim 107)$ in Koyna River specimens.

The fish fauna of Koyna is relatively less threatened by human activities, even though some stretches of the river are affected to a minor degree by pollution by sewage and agricultural activities. Near the Patan and Koynanagar areas, the river banks have brickmanufacturing units. The Koyna River in the vicinity of Koynanagar is also affected by dumping of organic waste as a result of the tourist industry in the area. Fishing pressure due to heavy harvest, using different sizes of gill-nets, could also be a threat to the larger fish species of the genera Cirrhinus, Gonoproktopterus, Labeo, Puntius, Schismatorhynchos, Tor, Salmophasia, Barilius and Clupisoma. A major part of the Koyna backwaters, however, is protected through the Koyna Wildlife Sanctuary.

We did not record any alien fishes in the Koyna River. Nevertheless, a number of studies suggest that the fish fauna of the Western Ghats is severely threatened by introduced alien species (Kharat et al. 2003; Wagh \& Ghate 2003; Daniels 2006; Raghavan et al. 2008; Knight 2010). Although we failed to record any introduced fish in the Koyna River, studies of other tributaries of the Krishna River in Satara and adjacent areas have recorded several alien fishes (Jayaram 1995).

We recorded six species from the Koyna River, considered as threatened by Menon (2004) on the grounds that they are either rare, habitat specific or because of inferred declines in their populations: Labeo porcellus, Puntius jerdoni, Rohtee ogilbii, Schismatorhynchos nukta, Tor khudree and Neotropius khavalchor. Further, Ghate et al. (2002) commented on the decline in the population of $S$. nukta from other rivers in Krishna River system. Apart from these species, the Koyna River has apparently abundant populations of Puntius sahyadriensis, Garra bicornuta, Botia striata and Clupisoma taakree, of which the last two species were considered as threatened by Dahanukar et al. (2004). The Koyna River appears to offer a potential refuge for the conservation of these species, evidently owing to the fact that these fishes are relatively less affected here by human activities.

In conclusion, there is a rich diversity of fishes 
in Koyna and it is relatively less threatened by anthropogenic stressors, even though there is a modest fishing pressure, tourism and organic pollution in some stretches of the river. Further, the fish fauna of Koyna River is not threatened by alien fish species. A major part of the Koyna River backwaters is also protected by the Koyna Wildlife Sanctuary. Thus, the Koyna River can be considered as a refuge for conservation of some endemic and threatened freshwater fishes of the Western Ghats. It is, however, essential that conservation efforts should ensure that the current status of the fish fauna is maintained by minimising anthropogenic impacts, especially the introduction of alien fish species.

\section{REFERENCES}

Annandale, N. (1919). Bombay streams fauna: notes on fresh water fish mostly from the Satara and Poona Districts. Records of the Indian Museum 16: 125-138.

Dahanukar, N., R. Raut \& A. Bhat (2004). Distribution, endemism and threat status of freshwater fishes in the Western Ghats of India. Journal of Biogeography 31(1): 123-136.

Daniels, R.J.R. (2006). Introduced fishes: a potential threat to the native freshwater fishes of peninsular India. Journal of the Bombay Natural History Society 103(2-3): 346-348.

David, A. (1963). Studies on fish and fisheries of the Godavari and Krishna river systems. Part 1. Proceedings of the National Academy of Science India 33(2): 263-293.

Eschmeyer, W.N. (ed.) (2010). Catalog of Fishes electronic version. <http://research.calacademy.org/ichthyology/ catalog/fishcatmain.asp $>$ On-line version dated 25 October 2010. Download on 22 December 2010.

Ghate, H.V., V.M. Pawar \& B.E. Yadav (2002). Note on cyprinoid fish Schismatorhynchos (Nukta) nukta (Sykes) from the Krishna drainage, Western Ghats. Zoos' Print Journal 17(7): 830-831.

Hora, S.L. (1938). Notes on fishes in the Indian Museum. XXXVIII. On the systematic position of Bagrus lonah Sykes, with descriptions of and remarks on other glyptosternoid fishes from Deccan. Records of Indian Museum 40:363375 .

Jayaram, K.C. (1991). Revision of the Genus Puntius Hamilton from the Indian Region (Pisces: Cypriniformes, Cyprinidae, Cyprininae). Occasional Paper No. 135. Records of the Zoological Survey of India, Kolkata, 178pp.

Jayaram, K.C. (1995). The Krishna River System: A Bioresources Study. Occasional Paper No. 160. Records of Zoological Society of India, 167pp.

Jayaram, K.C. (2010). The Freshwater Fishes of the Indian Region. Second Edition. Narendra Publishing House,
Delhi, 616pp.

Jayaram, K.C. \& A. Sanyal (2003). A Taxonomic Revision of the Fishes of the Genus Mystus Scopoli (Family: Bagridae). Occasional Paper No. 207. Records of the Zoological Survey of India, Kolkata, 136pp.

Jayaram, K.C. \& J.J. Dhas (2000). Revision of the Genus Labeo from Indian Region with a Discussion on its Phylogeny and Zoogeography. Occasional Paper No. 183. Records of the Zoological Survey of India, Kolkata, 143pp.

Kharat,S.S.,N.Dahanukar,R.Raut\&M.Mahabaleshwarkar (2003). Long term changes in freshwater fish species composition in north Western Ghats, Pune District. Current Science 84(6): 816-820.

Knight, J.D.M. (2010). Invasive ornamental fish: a potential threat to aquatic biodiversity in peninsular India. Journal of Threatened Taxa 2(2): 700-704.

Menon, A.G.K. (1964). Monograph of the cyprinid fishes of the genus Garra Hamilton. Memoirs of the Indian Museum 14(4): 173-260.

Menon, A.G.K. (1987). The Fauna of India and Adjacent Countries, Pisces, Vol 4, Teleostei-Cobitoidea, Part 1, Homalopteridae. Zoological Survey of India, Kolkata, 259pp.

Menon, A.G.K. (1992). The Fauna of India and Adjacent Countries, Pisces, Vol 4, Teleostei-Cobitoidea, Part 2 Cobitidae. Zoological Survey of India, Kolkata, 113pp.

Menon, A.G.K. (2004). Threatened Fishes of India and Their Conservation. Zoological Survey of India, Kolkata, 170pp.

Pethiyagoda, R.\& M. Kottelat (2005). The identity of the South Indian Barb Puntius mahecola (Teleostei: Cyprinidae). The Raffles Bulletin of Zoology Suppl. No. 12: 145-152.

Raghavan, R., G. Prasad, P.H. Anvar-Ali \& B. Pereira (2008). Exotic fish species in a global biodiversity hotspot: observations from river Chalakudy, part of Western Ghats, Kerala, India. Biological Invasions 10(1): 37-40.

Rui-Feng, S., Y. Jun-Xing \& C. Yin-Rui (2000). A review of the Chinese species of Crossocheilus, with description of a new species (Ostariophysi: Cyprinidae). The Raffles Bulletin of Zoology 48: 215-221.

Shaji, C.P., P.S. Easa \& A. Gopalakrishnan (2000). Freshwater fish diversity of Western Ghats, pp. 35-35. In: Ponniah, A.G. \& A. Gopalakrishnan (eds.). Endemic Fish Diversity of Western Ghats. NBFGR-NATP publication, National Bureau of Fish Genetic Resources, Lucknow, India, 347pp.

Silas, E.G. (1951). Notes on fishes of the genus Glyptothorax Blyth from peninsular India, with description of a new species. Journal of the Bombay Natural History Society 50(2): $367-370$.

Silas, E.G. (1953). Notes on the fishes from Mahabaleshwar and Wai (Satara District, Bombay State). Journal of the Bombay Natural History Society 51(3): 579-589.

Silas, E.G. \& E. Dawson (1961). Amphipnous indicus, a new synbranchoid eel from India, with a redefinition of the genus and a synopsis to the species of Amphipnous Müller. Journal of the Bombay Natural History Society 58(2): 366- 
378.

Sykes, W.H. (1839). On the fishes of the Deccan. Proceedings of the General Meetings for Scientific Business of the Zoological Society of London 6: 157-165.

Talwar, P.K. \& A.G. Jhingran (1991). Inland Fishes of India and Adjacent Countries. Oxford-IBH Publishing Co. Pvt. Ltd., New Delhi, 1158pp.

Wagh, G.K. \& H.V. Ghate (2003). Freshwater fish fauna of the rivers Mula and Mutha, Pune, Maharashtra. Zoos' Print Journal 18(1): 977-981. 